\title{
Mepazine Inhibits RANK-Induced Osteoclastogenesis Independent of Its MALT1 Inhibitory Function
}

\author{
Laura Meloni ${ }^{1,2}$, Lynn Verstrepen ${ }^{1,2}$, Marja Kreike ${ }^{1,2}$, Jens Staal ${ }^{1,2}, * \mathbb{C}$, Yasmine Driege ${ }^{1,2}$, \\ Inna S. Afonina ${ }^{1,2}$ and Rudi Beyaert 1,2,*(D) \\ 1 Unit of Molecular Signal Transduction in Inflammation, VIB-UGent Center for Inflammation Research, \\ VIB, 9052 Ghent, Belgium; laurameloni86@gmail.com (L.M.); lynn.verstrepen@prodigest.eu (L.V.); \\ marja.kreike@irc.vib-ugent.be (M.K.); yasmine.driege@irc.vib-ugent.be (Y.D.); \\ inna.afonina@irc.vib-ugent.be (I.S.A.) \\ 2 Department of Biomedical Molecular Biology, Ghent University, 9052 Ghent, Belgium \\ * Correspondence: Jens.Staal@irc.vib-UGent.be (J.S.); Rudi.Beyaert@irc.vib-UGent.be (R.B.); \\ Tel.: +32-9-3313770 (R.B.)
}

Received: 5 November 2018; Accepted: 27 November 2018; Published: 30 November 2018

\begin{abstract}
Mucosa-associated lymphoid tissue lymphoma translocation protein 1 (MALT1) is an intracellular cysteine protease (paracaspase) that plays an integral role in innate and adaptive immunity. The phenothiazine mepazine has been shown to inhibit the proteolytic activity of MALT1 and is frequently used to study its biological role. MALT1 has recently been suggested as a therapeutic target in rheumatoid arthritis. Here, we analyzed the effect of mepazine on the receptor activator of nuclear factor $\mathrm{k}-\mathrm{B}$ (RANK)-induced osteoclastogenesis. The treatment of mouse bone marrow precursor cells with mepazine strongly inhibited the RANK ligand (RANKL)-induced formation of osteoclasts, as well as the expression of several osteoclast markers, such as TRAP, cathepsin $\mathrm{K}$, and calcitonin. However, RANKL induced osteoclastogenesis equally well in bone marrow cells derived from wild-type and Malt1 knock-out mice. Furthermore, the protective effect of mepazine was not affected by MALT1 deficiency. Additionally, the absence of MALT1 did not affect RANK-induced nuclear factor $\mathrm{kB}(\mathrm{NF}-\mathrm{kB})$ and activator protein 1 (AP-1) activation. Overall, these studies demonstrate that MALT1 is not essential for RANK-induced osteoclastogenesis, and implicate a MALT1-independent mechanism of action of mepazine that should be taken into account in future studies using this compound.
\end{abstract}

Keywords: osteoclastogenesis; mepazine; MALT1; RANK; NF-kB; phenothiazine; paracaspase; osteoclast

\section{Introduction}

Phenothiazines are a family of chemical compounds characterized by a common tricyclic phenothiazine ring and a variable side chain. The nature of the side chain specifies different derivatives and determines their inhibitory potential toward various substrates [1]. Phenothiazines are best known from their long history as neuroleptic antipsychotic drugs due to their dopamine blocking properties [2]. Specific phenothiazines, including mepazine, were found to inhibit mucosa-associated lymphoid tissue lymphoma translocation 1 (MALT1) [3,4] and to exert therapeutic activity in preclinical models of several diseases, including multiple sclerosis [5], activated B cell subtype of diffuse-large B cell lymphoma (ABC-DLBCL) [3], viral infection [6,7], and colitis [8]. MALT1 (PCASP1 [9]) is an intracellular signaling protein that plays a key role in innate and adaptive immunity [10,11]. More specifically, MALT1 acts as a scaffold protein for downstream signaling proteins leading to NF- $\mathrm{KB}$ activation. In addition, MALT1 protease activity further fine-tunes gene expression by cleaving a number of substrates $[10,11]$. Its function is best known in the context of $T$ 
cell receptor-induced signaling leading to proliferation, survival, and activation of Tlymphocytes, but MALT1 also plays an important role in several other cell types, including myeloid cells and nonimmune cells [11]. We were interested in a potential role of MALT1 in the formation of osteoclasts from bone marrow precursor cells. Several phenothiazines were described to inhibit osteoclastic bone resorption in vivo and in vitro [12-19]. Mechanistically, the phenothiazines chlorpromazine, promethazine, and trifluoperazine were shown to inhibit the receptor activator of nuclear factor $\mathrm{kB}$ (RANK)-induced osteoclast differentiation from bone-marrow cells (BMCs) [19]. Mature osteoclasts are multinucleated giant bone resorbing-cells with the ability to degrade the mineralized matrices of bone and calcified cartilage [20]. Osteoclasts differentiate from hematopoietic stem cells and express specific differentiation markers: Tartrate-resistant acid phosphatase (TRAP), matrix metalloproteinase-9, cathepsin-K, carbonic anhydrase II, osteopetrosis-associated transmembrane protein 1, vacuolar type ATPase containing the a3 subunit, chloride channel, and the calcitonin receptor, both during development and as mature cells [20]. Macrophage-colony stimulating factor (M-CSF) and RANK ligand (RANKL) are two indispensable factors for osteoclastogenesis [21], and their deficiency in mice leads to a complete lack of osteoclasts [22]. In particular, M-CSF is necessary for the survival and the proliferation of preosteoclasts, while RANKL is required for their final differentiation. RANKL signaling results in the activation of different transcription factors, including nuclear factor $\mathrm{kB}$ (NF-KB) [23] and activator protein 1 (AP-1) [24]. In addition, RANKL potently induces the expression and activation of the nuclear factor of activated T cells cytoplasmic 1 (NFATc1), a master regulator of osteoclast differentiation [25]. Of interest, the MALT1 substrates A20 [26], CYLD [27], and RelB [28] have previously been associated with osteoclastogenesis. More specifically, CYLD was found to inhibit RANK-induced signaling by deubiquitinating TRAF6, and its physiological importance is reflected by the fact that CYLD-deficient mice develop osteoporosis, due to accelerated osteoclastogenesis [29]. In addition, mice with an A20 deficiency in myeloid cells showed enhanced osteoclastogenesis associated with the development of severe erosive polyarthritis [30]. Finally, RelB-mediated noncanonical NF- $\mathrm{KB}$ activation is required for full RANKL-induced osteoclast maturation [31]. The reported anti-osteoclastogenic effect of phenothiazines structurally related to the MALT1 inhibitor mepazine, as well as the function of some MALT1 substrates in osteoclastogenesis, led us to hypothesize a novel role for MALT1 in osteoclastogenesis. We therefore tested the effect of pharmacological and genetic MALT1 inhibition on RANK-induced osteoclastogenesis in vitro. We show that treatment of BMCs with mepazine completely inhibits RANK-induced osteoclastogenesis. However, we also found that mepazine is equally potent in the absence of MALT1, and that MALT1 deficiency does not affect RANK-induced signaling and osteoclastogenesis. These results exclude a role for MALT1 in RANK-induced osteoclastogenesis and implicate a MALT1-independent mechanism of action of mepazine that should be taken into account in future studies using this compound.

\section{Results}

\subsection{Mepazine Inhibits RANK-Induced Osteoclastogenesis Independent of MALT1}

Several phenothiazines were shown to inhibit RANK-induced osteoclast differentiation from BMCs [19]. To test if mepazine, a phenothiazine shown to inhibit MALT1 [3], has a similar anti-osteoclastogenic effect, we treated BMCs with M-CSF and RANKL in the presence or absence of mepazine. The mepazine concentration used was equal to the concentration that shows efficient inhibition of MALT1 protease activity in stimulated T cells [5]. At day 9, when osteoclast formation was microscopically visible in M-CSF plus RANKL-treated cells, cells were stained for the osteoclast marker TRAP. As shown in Figure 1, mepazine completely prevented RANKL-induced osteoclast differentiation, suggesting a potential novel role of MALT1 in osteoclastogenesis. However, in the same experiment, we also treated BMCs from both $\mathrm{Malt1}^{+/+}$and Malt1 $1^{-/-}$mice with M-CSF and RANKL, and found osteoclast formation to be equally induced in both wild-type and knock-out cells (Figure 1). These data illustrate that MALT1 is dispensable for RANKL-induced osteoclastogenesis, which also 
led us to question the MALT1-dependency of the protective effect observed with mepazine. Indeed, RANKL-induced osteoclast formation was equally inhibited by mepazine in Malt1 ${ }^{+/+}$and Malt $1^{-/-}$ cells (Figure 1), demonstrating that mepazine exerts an anti-osteoclastogenic effect independent of its MALT1 inhibitory capacity.

WT

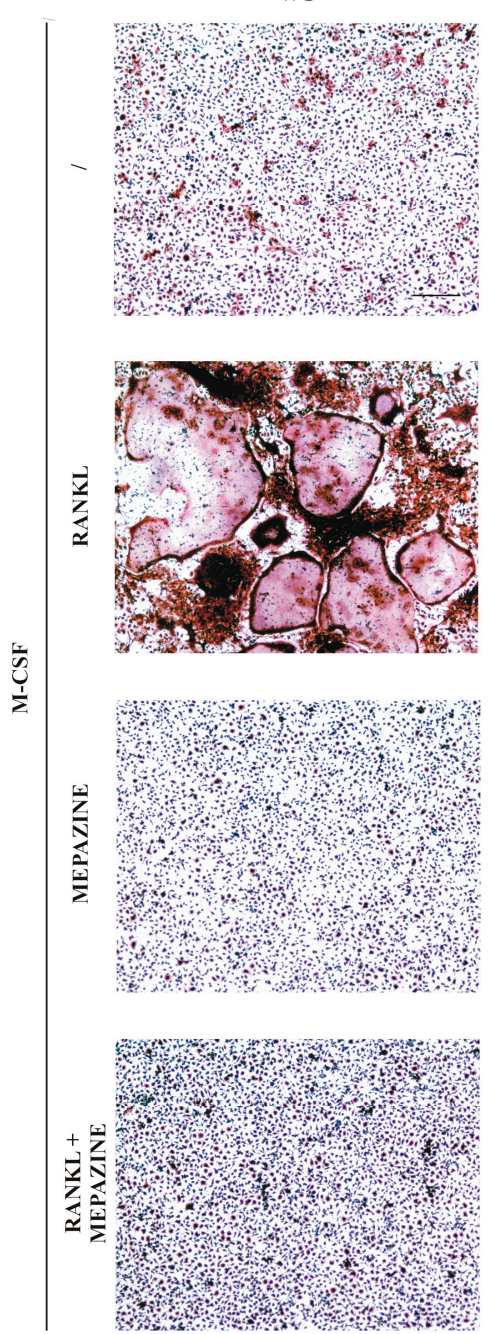

KO
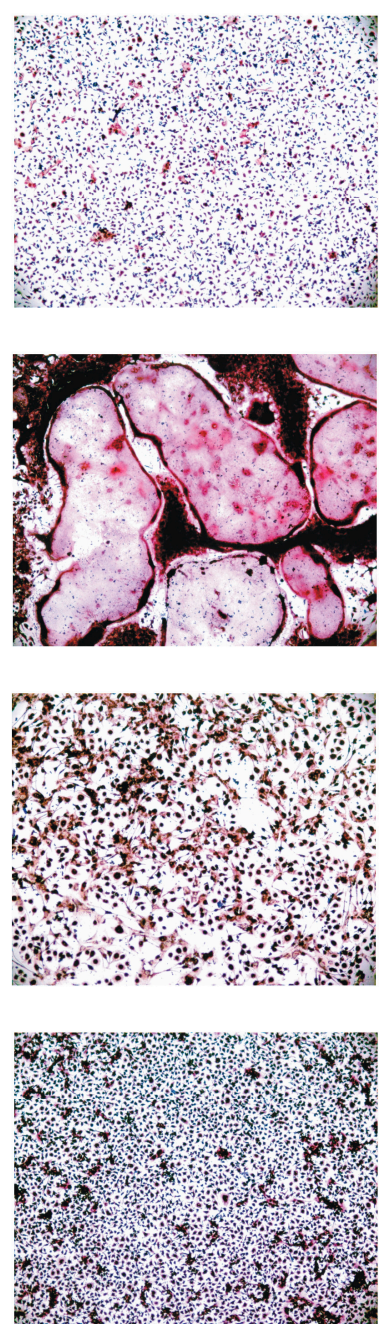

Figure 1. Mepazine inhibits RANK ligand (RANKL)-induced osteoclastogenesis independently of mucosa-associated lymphoid tissue lymphoma translocation (MALT1). Bone marrow cells (BMCs) isolated from wild-type (WT) and Malt1 knock-out (KO) mice were stimulated every two days with macrophage-colony stimulating factor (M-CSF) $(20 \mathrm{ng} / \mathrm{mL})$ plus RANKL $(50 \mathrm{ng} / \mathrm{mL})$ in the presence or absence of mepazine $(13 \mu \mathrm{M})$. Samples without mepazine were treated with an equal volume ( $0.1 \%$ final concentration) of DMSO as solvent control. The / symbol represents that no RANKL or mepazine was added. At day 9, cells were fixed and stained for tartrate-resistant acid phosphatase (TRAP). Microscopic analysis shows the appearance of very large multinucleated TRAP-positive cells (=typical for osteoclasts) after M-CSF plus RANKL treatment. Scale bar represents $100 \mu \mathrm{m}$. Results are representative of three independent experiments.

To further exclude the role of MALT1 in the inhibitory effect of mepazine on osteoclast development, RANKL-induced osteoclast-specific gene expression in Malt1 wild-type and MALT1-deficient cells was tested in the presence or absence of mepazine. As shown in Figure 2, RANKL clearly upregulated osteoclast-specific genes, like TRAP, CTSK (cathepsin K), and CALCR (calcitonin receptor), both in wild-type and MALT1-deficient cells, highlighting that MALT1 is dispensable for RANK-induced osteoclastogenesis. Of note, absence of MALT1 even slightly increased RANK-induced 
gene expression for reasons that are still unclear. Most importantly, RANK-induced gene expression was strongly reduced by mepazine in both $\mathrm{Malt1}^{+/+}$and $\mathrm{Malt1}^{-/}$cells, further demonstrating that the inhibitory effect of mepazine on osteoclast formation is MALT1-independent.

(a)

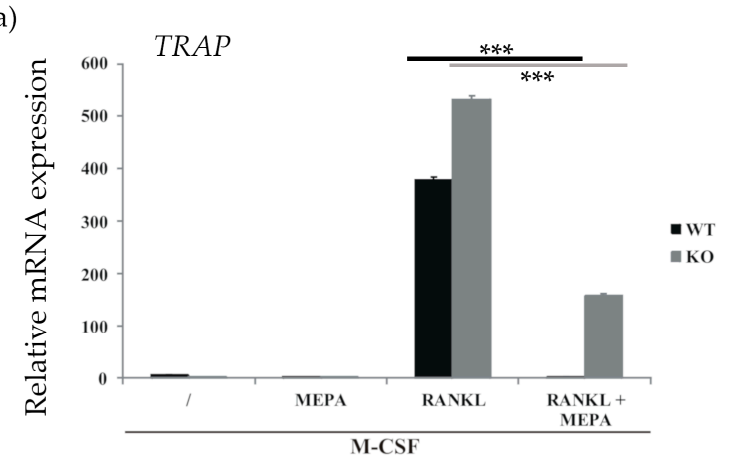

(b)

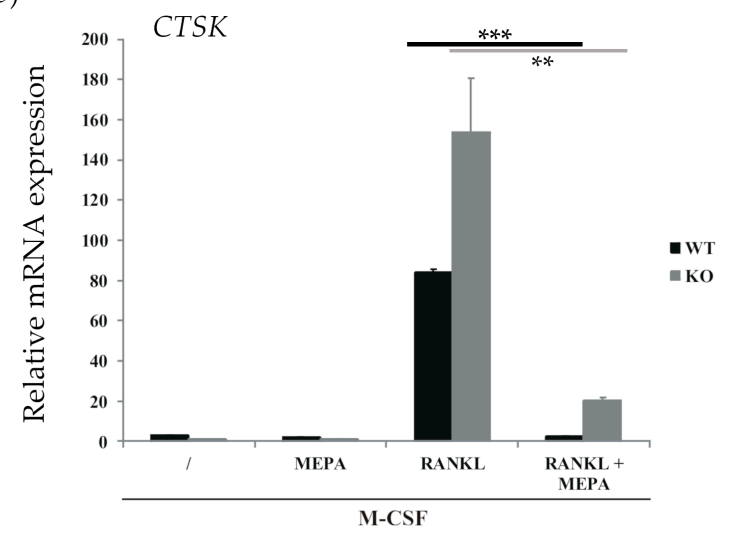

(c)

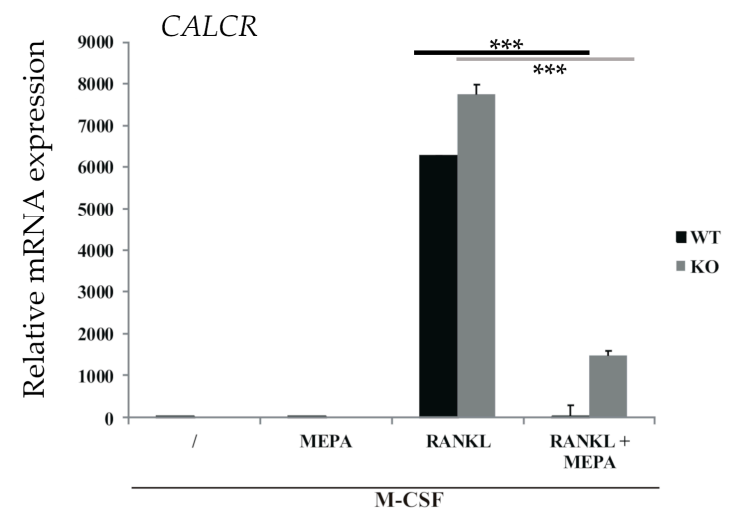

Figure 2. MALT1-independent inhibition of osteoclast-specific gene induction by mepazine. BMCs isolated from Malt1 wild-type (WT) and Malt1 knock-out (KO) mice were differentiated into osteoclasts by treatment with M-CSF $(20 \mathrm{ng} / \mathrm{mL})$, as well as RANKL $(50 \mathrm{ng} / \mathrm{mL})$ in the presence or absence of mepazine (MEPA, $13 \mu \mathrm{M}$ ) every two days. Samples without mepazine were treated with an equal volume ( $0.1 \%$ final concentration) DMSO as solvent control. The / symbol represents that no RANKL or mepazine was added. mRNA was extracted at day 9 and qPCR was performed for (a) TRAP, (b) CTSK (Cathepsin K) and (c) CALCR (Calcitonin receptor). Values are the mean of technical triplicates \pm S.D. Data are representative of two independent experiments. Statistical differences were determined by Student's $t$-test, ${ }^{* *}$ represents $p \leq 0.01$ and ${ }^{* * *}$ represents $p \leq 0.001$. 


\subsection{MALT1 Is not Involved in RANK-Induced NF- $\kappa B$ and AP1 Signaling}

Engagement of RANKL with its receptor RANK induces NF-KB and AP-1 activation, which plays an important role in osteoclastogenesis [32,33]. To analyze the role of MALT1 in RANK-induced NF- $\mathrm{kB}$ and AP-1 signaling, we transfected MALT1-deficient HEK293T cells with RANK, whose overexpression is known to activate downstream signaling in a ligand-independent manner [34,35], and either a NF-kB-dependent or AP-1-dependent luciferase reporter plasmid. We similarly analyzed the effect in MALT1-deficient HEK293T cells that were reconstituted with MALT1. Expression levels of transfected RANK and MALT1 were checked via western blotting (Figure 3a). RANK overexpression reproducibly increased the expression of co-transfected MALT1, most likely reflecting effects of RANK signaling on the activity of the cytomeglavirus (CMV) promoter that drives MALT1 expression [36,37]. Most importantly, RANK overexpression activated NF- $\mathrm{KB}$ and AP-1-dependent reporter gene expression equally well in MALT1-deficient and MALT1-expressing cells (Figure 3b), demonstrating that NF- $\mathrm{KB}$ and AP-1 signaling in response to RANK activation is MALT1-independent. These results are consistent with our observation that RANKL-induced osteoclastogenesis is MALT1-independent, and further support our conclusion that mepazine inhibits RANK-induced osteoclastogenesis independent of its MALT1 inhibitory activities.

(a)

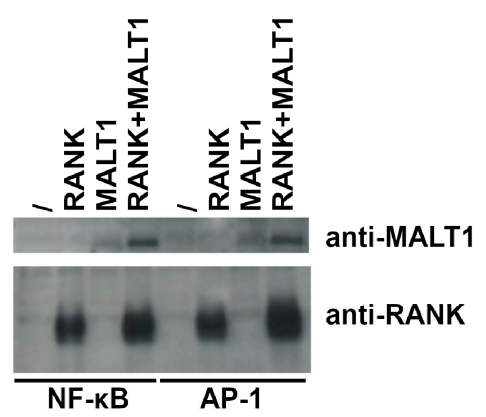

(b)
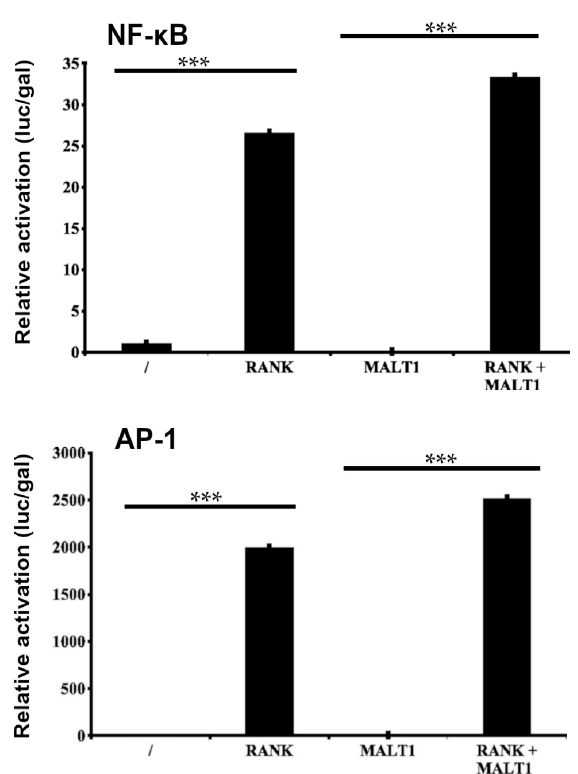

Figure 3. MALT1 is not necessary for RANK-induced NF-kB and AP-1 signaling. MALT1-deficient HEK293T cells or cells reconstituted with MALT1 (as indicated on the X-axis) were transiently transfected with a RANK expression plasmid, a plasmid constitutively expressing $\beta$-galactosidase, and plasmids expressing either an NF- $\mathrm{BB}$-dependent or AP-1-dependent luciferase reporter gene. The / represents set-ups where neither RANK nor MALT1 is expressed. Statistical differences were determined by Student's $t$-test, ${ }^{* * *}$ represents $p \leq 0.001$. (a) Expression of MALT1 and RANK was verified by Western blotting. The four left lanes correspond to the samples analyzed in (b) for NF- $\mathrm{kB}$ reporter activation, the last four lanes correspond to the samples analyzed in (b) for AP-1 reporter activation. (b) Luciferase activity was measured $24 \mathrm{~h}$ after transfection and normalized to $\beta$-galactosidase expression (plotted as luc/gal). Values are the mean of triplicates \pm S.D. Data shown are representative of two independent experiments.

\subsection{Mepazine Inhibits CaMKII Phosphorylation and NFATc1 Expression Independently of MALT1}

Besides NF- $\mathrm{kB}$ signaling, the transcription factor NFATc1 also plays an integral role in the RANKL-induced transcriptional program during the terminal differentiation of osteoclasts. NFATc1 is strongly induced and activated by RANKL via a mechanism that is dependent on the 
$\mathrm{Ca}^{2+} /$ calmodulin-regulated phosphatase, calcineurin [25]. The chemical structure of mepazine contains two hydrophobic groups and an N group (Figure 4a), which are the essential structural elements in other phenothiazines (for example, Promethazine, Chlorpromazine, and Trifluoperazine (Figure $4 b-d$ )) that were previously shown to inhibit calmodulin activity [38]. Earlier studies suggest that the critical $\mathrm{N}$ group is positively charged by binding a proton under physiological $\mathrm{pH}$, and that this contributes to electrostatic interactions with the negatively charged calmodulin [38]. It is therefore likely that mepazine affects osteoclast differentiation by inhibiting the calmodulin-dependent expression and activation of NFAT. Indeed, mepazine completely prevented RANK-induced NFATc1 expression in M-CSF treated BMCs (Figure 4e), indicating that mepazine may exert its anti-osteoclastogenic function by inhibiting calmodulin-dependent NF-AT1 expression and activation.

(a)

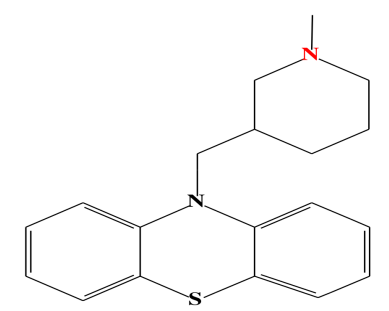

(c)

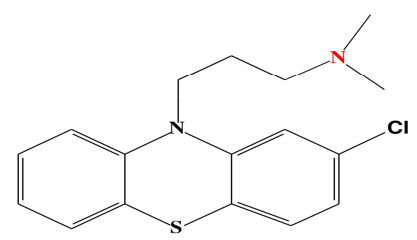

(b)<smiles>CC(C)CC1C2CC=CCC2CC2CC=CCC21</smiles>

(d)

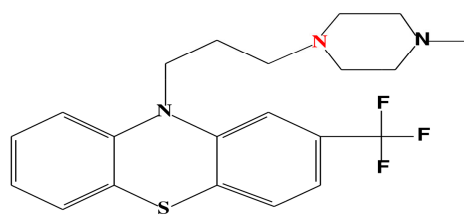

(e)

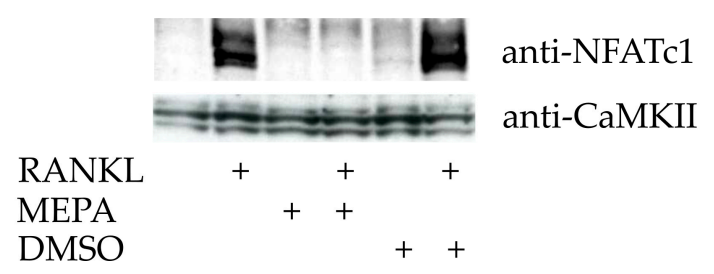

Figure 4. Mepazine inhibits RANKL-induced NF-AT1 expression. (a) Molecular structure of Mepazine (b) Promethazine (c) Chlorpromazine (d) Trifluoperazine, with the critical N group proposed to influence calmodulin highlighted in red. (e) As in Figures 1 and 2, BMCs were stimulated for 9 days with M-CSF (20 ng/mL) plus RANKL (50 ng/mL) in the presence or absence of mepazine (MEPA; $13 \mu \mathrm{M})$ or DMSO (0.1\% final concentration) as solvent control every two days. Cell lysates were analyzed by Western blot for NFATc1 expression. CaMKII expression is used as loading control.

\section{Discussion}

In the present study, we show that the MALT1 inhibitor mepazine strongly inhibits RANK-induced osteoclastogenesis via a MALT1-independent mechanism. Mepazine has been frequently used in several in vitro and in vivo studies to demonstrate a role for MALT1 [3-8,39-44]. Most importantly, the therapeutic effect of mepazine in mouse models of autoimmune disease and ABC-type DLBCL has strengthened the belief in therapeutic targeting of MALT1. The rationale for MALT1 as a therapeutic target is based on much more evidence than the inhibitory effect of mepazine, including supportive evidence by other MALT1 inhibitors and genetic inactivation of MALT1 protease activity in mouse models [11]. However, it cannot be excluded that the observed therapeutic effects of mepazine in these previous studies also partially reflect some of its MALT1-independent activities. Care should therefore 
be taken in the future when interpreting results obtained with this inhibitor. A recent report suggested inhibition of osteoclastogenesis and protection in a model of rheumatoid arthritis by the structurally unrelated MALT1 active site inhibitor MI-2 [45]. However, this study did not control for a possible role of off-target activities of MI-2, which was recently shown to be a very nonspecific inhibitor [46]. This highlights the need to verify on-target effects of an inhibitor when used for studying the biological role of its presumed target, preferably by also doing inhibitor treatments of a genetic knock-out of the intended target protein [47].

Independent of the involvement of MALT1, the clear protective effect of mepazine on RANK-induced osteoclastogenesis is of significant therapeutic interest because of its previous clinical use as an antipsychotic drug [2]. More specifically, mepazine was commercialized in the late 1950s under the name Pacatal and administered as a tranquilizer to treat anxiety, aggression, and impulsiveness [48]. It was subsequently removed from the market in the late 1960s because its efficacy was not significant or close to zero compared to other available antipsychotic drugs [49]. Moreover, it presented some side effects, such as granulocytopenia, hypotension, urinary retention, and paralytic ileus [50]. Nevertheless, because of its MALT1 inhibitory effects, a repurposing of mepazine for the treatment of autoimmunity and ABC-DLBCL has been proposed [4]. Our present observation that mepazine inhibits osteoclastogenesis via a different pathway further strengthens the therapeutic potential of mepazine. In fact, a recent patent application reports that mepazine treatment protects mice from the development of arthritis in a collagen-induced arthritis model [51]. As a matter of fact, it is shown that treatment with mepazine leads to a reduction in pannus formation and bone resorption, indicating a decrease in the number of osteoclasts, which is in line with our in vitro results.

Our observation that RANK-induced osteoclastogenesis proceeds equally well in wild-type versus Malt1 knock-out cells allows us to conclude that MALT1 is dispensable for RANK-induced osteoclastogenesis in vitro. Nevertheless, these results do not exclude a role for MALT1 in osteoclastogenesis via other RANK-independent mechanisms. In this context, MALT1 has been linked to signaling downstream of the ITAM-containing adaptor proteins DAP12 and Fc $\gamma \mathrm{R}$ [52], which cooperate with the immunoreceptors TREM-2 and OSCAR as co-stimulators of RANK-induced osteoclastogenesis [53,54]. Lately, it has been shown that DAP12 stimulation through IL-23, a cytokine belonging to the IL-12 family, is able to induce osteoclastogenesis through the activation of NFATc1 [55]. In addition, desialylated immunoglobulin $\mathrm{G}(\mathrm{IgG})$ immune complexes were recently shown to increase osteoclastogenesis in vivo and in vitro via binding to Fc $\gamma$ RII and Fc $\gamma$ RIII, but not Fc $\gamma$ RI [56]. Therefore, it could be of interest to evaluate a possible difference in the number of osteoclasts in $\mathrm{Malt1}^{+/+}$and Malt1 ${ }^{-/-}$mice by ex vivo TRAP staining on bone slices or by measuring bone density using a CT scan. It should be mentioned, however, that Malt1 ${ }^{-/-}$mice suffer from Treg deficiency, which is known to contribute to increased osteoclastogenesis and decreased bone density [57]. This implies that one can expect $M a l t 1^{-/-}$mice to have a lower bone density, independent from a direct role of MALT1 in osteoclastogenesis. Final proof for a direct role of MALT1 in osteoclastogenesis would therefore need the use of osteoclast-specific Malt1 ${ }^{-/-}$mice. Of interest, MALT1 deficiency in patients has been associated with combined immunodeficiency, and a case of human MALT1 deficiency in a 15-year-old female was shown to experience significant growth delay with short stature, low weight, and delayed bone age [58]. Moreover, she had very low bone mineral density and fractured her femur and both tibiae after low-impact injuries, which were reversed after transplantation of healthy hemapoetic stem cells [58,59].

It will be of interest to identify the real target of mepazine that is responsible for its protective effect against RANK-induced osteoclastogenesis. Our results indicate that mepazine is influencing the $\mathrm{Ca}^{2+}$-dependent signaling pathway for osteoclastogenesis, possibly via a direct effect on calmodulin. It is worth mentioning that the $\mathrm{Ca}^{2+}$-calmodulin-calcineurin pathway is also involved in $\mathrm{T}$ cell receptor (TCR) signaling. For example, CaMKII is able to phosphorylate BCL10 [60,61] and CARMA1 [62], while calcineurin is able to dephosphorylate BCL10 [63], two components of the CBM complex, where MALT1 represents the third component. Therefore, it is not unlikely that some of the reported 
effects of mepazine on TCR-induced immune responses reflect not only its effect on MALT1, but also on calcineurin. In this context, it is worth mentioning that the calcineurin inhibitor cyclosporine A is well known because of its immunosuppressive activities [64]. The field is clearly in need for more specific small compound inhibitors of MALT1, and several new developments seem to go into this direction [46].

\section{Materials and Methods}

\subsection{Mice}

Malt1 ${ }^{-/-}$mice [65], backcrossed to C57BL/ 6 mice, were kindly provided by Dr. Tak W. Mak (Ontario Cancer Institute, Toronto, ON, Canada). Malt $1^{-/+}$mice were intercrossed to generate Malt1 ${ }^{+/+}$, Malt $1^{-/+}$, and Malt1 ${ }^{-/-}$offspring. Mice were housed in individually ventilated cages in a specific pathogen-free animal facility. Mice were supplied with water and food ad libitum. Euthanasia was performed in compliance with the local guidelines of the University of Ghent Ethics Committee. All experiments were performed ex vivo on cells isolated from euthanized mice. Both male and female mice were used at an age of 8 to 12 weeks.

\subsection{Osteoclast Cell Culture and TRAP Staining}

Mouse BMCs were obtained from tibiae as previously described [66] and $2 \times 10^{6}$ cells were seeded and cultured for 10 days in 6-well dishes in $\alpha$-MEM (Minimal Essential Medium Alpha, Thermo Fisher Scientific, Waltham, MA, USA) with 10\% fetal bovine serum (FBS) (Thermo Fisher Scientific, Waltham, MA, USA), $100 \mathrm{IU} / \mathrm{mL}$ penicillin and $100 \mu \mathrm{g} / \mathrm{mL}$ streptomycin (Thermo Fisher Scientific, Waltham, MA, USA). Cells were stimulated every 2 days with $20 \mathrm{ng} / \mathrm{mL}$ M-CSF (Protein Service Facility, VIB, Ghent, Belgium) and $50 \mathrm{ng} / \mathrm{mL}$ RANKL (Bio-Techne, R\&D Systems, Minneapolis, MN, USA) to obtain osteoclasts. Mepazine acetate (kindly provided by Dr. Krappmann) was dissolved in DMSO and added to the cells at a concentration of $4.5 \mu \mathrm{g} / \mathrm{mL}(13 \mu \mathrm{M})$ every 2 days. The Mepazine concentration was chosen based on what we previously had found an efficient dose to block MALT1 protease activity in stimulated T cells [5]. On day 9, osteoclasts were stained for TRAP using the Acid Phosphatase, Leukocyte (TRAP) kit according to manufacturer's instructions (Sigma-Aldrich Corporation, Saint Louis, MO, USA). Pictures were taken with an Olympus BX51 discussion microscope (Olympus, Tokyo, Japan) with 10X dry objective (0.25 NA).

\subsection{Quantitative Real-Time Polymerase Chain Reaction ( $q R T-P C R)$}

On day 9, $500 \mu \mathrm{L}$ TRIzol reagent (ThermoFisher Scientific) was added to the cells and total RNA was isolated using the Aurum Total RNA Isolation Mini Kit according to the manufacturer's instructions (Bio-Rad, Hercules, CA, USA). cDNA was prepared from $1 \mu \mathrm{g}$ of total RNA using the iScript cDNA synthesis kit according to the manufacturer's instructions (Bio-Rad, Hercules, CA, USA). qPCR was performed with SensiFAST ${ }^{\mathrm{TM}}$ Sybr No-ROX kit (Bioline, London, UK) and specific primers on a LightCycler 480 (Roche, Basel, Switzerland). Real-time PCR reactions were performed in triplicates and analyzed via the qBASE program (Biogazelle, Ghent, Belgium). mRNA expression of the genes of interest, measured by qPCR, was normalized by the program to the expression of the housekeeping genes, and the error bars on the graphs represent the standard error of the mean (SEM) of three technical replicates. The following specific forward (FW) and reverse (REV) primers were used:

\begin{tabular}{cccc}
\hline ACTIN FW & GCTTCTAGGCGGACTGTTACTGA & MALT1 FW & GGACAAAGTCGCCCTTTTGAT \\
\hline ACTIN REV & GCCATGCCAATGTTGTCTCTTAT & MALT1 REV & TCCACAGCGTTACACATCTCA \\
\hline GADPH FW & TGAAGCAGGCATCTGAGGG & TRAP FW & TGGTCCAGGAGCTTAACTGC \\
\hline GADPH REV & CGAAGGTGGAAGAGTGGGAG & TRAP REV & GTCAGGAGTGGGAGCCATATG \\
\hline CATHEPSIN K FW & GTGGGTGTTCAAGTTTCTGC & CALCITONIN receptor FW & CTCCAACAAGGTGCTTGGGA \\
\hline CATHEPSIN K REV & GGTGAGTCTTCTTCCATAGC & CALCITONIN receptor REV & GAAGCAGTAGATAGTCGCCA \\
\hline
\end{tabular}




\subsection{Luciferase Assay and Western Blot Analysis}

MALT1-deficient HEK293T cells (clone \#36), which have been used to determine MALT1-dependent pathways in several previous studies $[9,41,67]$, were cultured in Dulbecco's modified Eagle's medium (DMEM), supplemented with 10\% fetal calf serum and $2 \mathrm{mM}$ L-glutamine. For luciferase assays, 50,000 MALT1 deficient HEK293T cells were seeded, and the day after, transiently transfected by the calcium phosphate precipitation method with specific expression plasmids, NF-kBor AP-1-dependent luciferase reporter plasmids, and a constitutively expressed $\beta$-galactosidase reporter plasmid, as indicated. All plasmids were obtained from the BCCM/GeneCorner (www. genecorner.ugent.be) plasmid collection, Ghent, Belgium: pMX-RANK (LMBP 8952), pCD-MK (MALT1) (LMBP 5536), pNFconLuc (LMBP 3248), 3× AP1 pGL3 (LMBP 8820), pACT $3 G a l$ (LMBP 4341). $24 \mathrm{~h}$ after transfection, cells were lysed in $200 \mu \mathrm{L}$ lysis buffer $(25 \mathrm{mM}$ Tris-phosphate $\mathrm{pH}$ 7.8, 2 mM dithiothreitol, $2 \mathrm{mM} \mathrm{1,2-cyclohexanediaminetetraacetic} \mathrm{acid,} \mathrm{10 \%} \mathrm{glycerol} \mathrm{and} \mathrm{1 \%} \mathrm{Triton}$ X-100). Luciferase activity was measured in the Glomax luminometer (Promega, Madison, WI, USA) upon addition of substrate buffer to a final concentration of $470 \mu \mathrm{M}$ luciferin, $270 \mu \mathrm{M}$ co-enzyme A and $530 \mu \mathrm{M}$ ATP. $\beta$-Galactosidase activity was assayed with chlorophenol red $\beta$-galactopyranoside substrate (Roche Molecular Biochemicals, Vilvoorde, Belgium) and the absorbance was measured with a Benchmark microplate reader (iMark, Bio-Rad, Hercules, CA, USA). NF-kB and AP-1-dependent expression of luciferase are presented relative to the constitutive expression of $\beta$-galactosidase to normalize for potential differences in transfection efficiency.

For Western blot analysis, cells were lysed in Laemmli buffer, heated to $95^{\circ} \mathrm{C}$, loaded onto an SDS-polyacrylamide gel and transferred to a nitrocellulose blot by semi-dry immunoblotting. Blots were incubated with anti-RANK (sc-374360, Santa Cruz Biotechnology, Dallas, TX, USA), anti-MALT1 (sc-46677, Santa Cruz Biotechnology, Dallas, TX, USA), NFAT1c (556602, BD Pharmingen, Erembodegem, Belgium) or CaMKII (3362, Cell Signaling Technology Inc., Leiden, The Netherlands) primary antibodies, and horse radish peroxidase (HRP)-conjugated anti-rabbit or anti-mouse IgG secondary antibodies (GE Healthcare Life Sciences, Diegem, Belgium), followed by detection via enhanced chemiluminescence.

\subsection{Chemical Drawings}

Chemical structures were drawn with Chemtool (http:/ / ruby.chemie.uni-freiburg.de/ \{\}martin/ chemtool/chemtool.html) [68] and further adjusted in Inkscape (www.inkscape.org).

Author Contributions: Conceptualization, R.B., L.V., L.M and I.S.A.; methodology and materials, L.M, L.V, J.S. and Y.D.; investigation, L.M, L.V., M.K.; writing-original draft preparation, L.M.; writing-review and editing, L.V., R.B, I.S.A. and J.S.; supervision, R.B.; project administration, R.B.; funding acquisition, R.B.

Funding: Research in the authors' lab is supported by grants from the 'Fund for Scientific Research Flanders (FWO)', 'Belgian Foundation Against Cancer', 'Ghent University Concerted Research Actions (GOA)'. L.V. and I.A. are supported by a postdoctoral fellowship from the FWO.

Conflicts of Interest: The authors declare no conflicts of interest.

\section{References}

1. Jaszczyszyn, A.; Gassiorowski, K.; Świątek, P.; Malinka, W.; Cieślik-Boczula, K.; Petrus, J.; Czarnik-Matusewicz, B. Chemical structure of phenothiazines and their biological activity. Pharmacol. Rep. 2012, 64, 16-23. [CrossRef]

2. Pluta, K.; Morak-Młodawska, B.; Jeleń, M. Recent progress in biological activities of synthesized phenothiazines. Eur. J. Med. Chem. 2011, 46, 3179-3189. [CrossRef] [PubMed]

3. Nagel, D.; Spranger, S.; Vincendeau, M.; Grau, M.; Raffegerst, S.; Kloo, B.; Hlahla, D.; Neuenschwander, M.; Peter von Kries, J.; Hadian, K.; et al. Pharmacologic inhibition of MALT1 protease by phenothiazines as a therapeutic approach for the treatment of aggressive ABC-DLBCL. Cancer Cell. 2012, 22, 825-837. [CrossRef] [PubMed] 
4. Schlauderer, F.; Lammens, K.; Nagel, D.; Vincendeau, M.; Eitelhuber, A.C.; Verhelst, S.H.L.; Kling, D.; Chrusciel, A.; Ruland, J.; Krappmann, D.; et al. Structural Analysis of Phenothiazine Derivatives as Allosteric Inhibitors of the MALT1 Paracaspase. Angew. Chem. Int. Ed. 2013, 52, 10384-10387. [CrossRef] [PubMed]

5. Mc Guire, C.; Elton, L.; Wieghofer, P.; Staal, J.; Voet, S.; Demeyer, A.; Nagel, D.; Krappmann, D.; Prinz, M.; Beyaert, R.; et al. Pharmacological inhibition of MALT1 protease activity protects mice in a mouse model of multiple sclerosis. J. Neuroinflamm. 2014, 11, 124. [CrossRef] [PubMed]

6. Kip, E.; Staal, J.; Verstrepen, L.; Tima, H.G.; Terryn, S.; Romano, M.; Lemeire, K.; Suin, V.; Hamouda, A.; Kalai, M.; et al. MALT1 controls attenuated rabies virus by inducing early inflammation and $\mathrm{T}$ cell activation in the brain. J. Virol. 2018, 92, e02029-17. [CrossRef] [PubMed]

7. Kip, E.; Staal, J.; Tima, H.G.; Verstrepen, L.; Romano, M.; Lemeire, K.; Suin, V.; Hamouda, A.; Baens, M.; Libert, C.; et al. Inhibition of MALT1 decreases neuroinflammation and pathogenicity of virulent rabies virus in mice. J. Virol. 2018, 92, e00720-18. [CrossRef] [PubMed]

8. Liu, W.; Guo, W.; Hang, N.; Yang, Y.; Wu, X.; Shen, Y.; Cao, J.; Sun, Y.; Xu, Q. MALT1 inhibitors prevent the development of DSS-induced experimental colitis in mice via inhibiting NF- $\mathrm{kB}$ and NLRP3 inflammasome activation. Oncotarget 2016, 7, 30536-30549. [CrossRef] [PubMed]

9. Hulpiau, P.; Driege, Y.; Staal, J.; Beyaert, R. MALT1 is not alone after all: Identification of novel paracaspases. Cell. Mol. Life Sci. 2016, 73, 1103-1116. [CrossRef] [PubMed]

10. Afonina, I.S.; Elton, L.; Carpentier, I.; Beyaert, R. MALT1-a universal soldier: Multiple strategies to ensure NF- $\mathrm{kB}$ activation and target gene expression. FEBS J. 2015, 282, 3286-3297. [CrossRef] [PubMed]

11. Demeyer, A.; Staal, J.; Beyaert, R. Targeting MALT1 Proteolytic Activity in Immunity, Inflammation and Disease: Good or Bad? Trends Mol. Med. 2016. [CrossRef] [PubMed]

12. Komoda, T.; Ikeda, E.; Nakatani, Y.; Sakagishi, Y.; Maeda, N.; Kato, T.; Kumegawa, M. Inhibitory effect of phenothiazine derivatives on bone in vivo and osteoblastic cells in vitro. Biochem. Pharmacol. 1985, 34, 3885-3889. [CrossRef]

13. Chikuma, T.; Ishii, Y.; Kato, T.; Kurihara, N.; Hakeda, Y.; Kumegawa, M. Effect of chlorpromazine on PZ-peptidase and several other peptidase activities in cloned osteoblastic cells (MC3T3-E1). Biochem. Pharmacol. 1987, 36, 4319-4324. [CrossRef]

14. Hall, T.J.; Schaueblin, M. Promethazine inhibits osteoclastic bone resorption in vitro. Calcif. Tissue Int. 1994, 55, 68-70. [CrossRef] [PubMed]

15. Goldhaber, P.; Rabadjija, L. Effect of promethazine hydrochloride on bone resorption in tissue culture. Exp. Biol. Med. 1982, 169, 105-109. [CrossRef]

16. Zhang, L.; Feng, X.; McDonald, J.M. The role of calmodulin in the regulation of osteoclastogenesis. Endocrinology 2003, 144, 4536-4543. [CrossRef] [PubMed]

17. de Lima, V.; Bezerra, M.M.; de Menezes Alencar, V.B.; Vidal, F.D.; da Rocha, F.A.; de Castro Brito, G.A.; de Albuquerque Ribeiro, R. Effects of chlorpromazine on alveolar bone loss in experimental periodontal disease in rats. Eur. J. Oral Sci. 2000, 108, 123-129. [CrossRef] [PubMed]

18. Hall, T.J.; Nyugen, H.; Schaeublin, M.; Michalsky, M.; Missbach, M. Phenothiazines are potent inhibitors of osteoclastic bone resorption. Gen. Pharmacol. 1996, 27, 845-848. [CrossRef]

19. Kawamura, H.; Arai, M.; Togari, A. Inhibitory effect of chlorpromazine on RANKL-induced osteoclastogenesis in mouse bone marrow cells. J. Pharmacol. Sci. 2011, 117, 54-62. [CrossRef] [PubMed]

20. Henriksen, K.; Bollerslev, J.; Everts, V.; Karsdal, M.A. Osteoclast activity and subtypes as a function of physiology and pathology-implications for future treatments of osteoporosis. Endocr. Rev. 2011, 32, 31-63. [CrossRef] [PubMed]

21. Boyle, W.J.; Simonet, W.S.; Lacey, D.L. Osteoclast differentiation and activation. Nature 2003, 423, 337-342. [CrossRef] [PubMed]

22. Dougall, W.C.; Glaccum, M.; Charrier, K.; Rohrbach, K.; Brasel, K.; De Smedt, T.; Daro, E.; Smith, J.; Tometsko, M.E.; Maliszewski, C.R.; et al. RANK is essential for osteoclast and lymph node development. Genes Dev. 1999, 13, 2412-2424. [CrossRef] [PubMed]

23. Nakashima, T.; Hayashi, M.; Takayanagi, H. New insights into osteoclastogenic signaling mechanisms. Trends Endocrinol. Metab. 2012, 23, 582-590. [CrossRef] [PubMed]

24. Wagner, E.F.; Eferl, R. Fos/AP-1 proteins in bone and the immune system. Immunol. Rev. 2005, 208, $126-140$. [CrossRef] [PubMed] 
25. Takayanagi, H.; Kim, S.; Koga, T.; Nishina, H.; Isshiki, M.; Yoshida, H.; Saiura, A.; Isobe, M.; Yokochi, T.; Inoue, J.; et al. Induction and Activation of the Transcription Factor NFATc1 (NFAT2) Integrate RANKL Signaling in Terminal Differentiation of Osteoclasts. Dev. Cell. 2002, 3, 889-901. [CrossRef]

26. Coornaert, B.; Baens, M.; Heyninck, K.; Bekaert, T.; Haegman, M.; Staal, J.; Sun, L.; Chen, Z.J.; Marynen, P.; Beyaert, R. T cell antigen receptor stimulation induces MALT1 paracaspase-mediated cleavage of the NF- $\mathrm{kB}$ inhibitor A20. Nat. Immunol 2008, 9, 263-271. [CrossRef] [PubMed]

27. Staal, J.; Driege, Y.; Bekaert, T.; Demeyer, A.; Muyllaert, D.; Damme, P.V.; Gevaert, K.; Beyaert, R. T-cell receptor-induced JNK activation requires proteolytic inactivation of CYLD by MALT1. EMBO J. 2011, 30, 1742-1752. [CrossRef] [PubMed]

28. Hailfinger, S.; Nogai, H.; Pelzer, C.; Jaworski, M.; Cabalzar, K.; Charton, J.E.; Guzzardi, M.; Décaillet, C.; Grau, M.; Dörken, B.; et al. Malt1-Dependent RelB Cleavage Promotes Canonical NF-kB Activation in Lymphocytes and Lymphoma Cell Lines. Proc. Natl. Acad. Sci. 2011, 108, 14596-14601. [CrossRef] [PubMed]

29. Jin, W.; Chang, M.; Paul, E.M.; Babu, G.; Lee, A.J.; Reiley, W.; Wright, A.; Zhang, M.; You, J.; Sun, S.C. Deubiquitinating enzyme CYLD negatively regulates RANK signaling and osteoclastogenesis in mice. J. Clin. Investig. 2008, 118, 1858-1866. [CrossRef] [PubMed]

30. Matmati, M.; Jacques, P.; Maelfait, J.; Verheugen, E.; Kool, M.; Sze, M.; Geboes, L.; Louagie, E.; Mc Guire, C.; Vereecke, L.; et al. A20 (TNFAIP3) deficiency in myeloid cells triggers erosive polyarthritis resembling rheumatoid arthritis. Nat. Genet. 2011, 43, 908-912. [CrossRef] [PubMed]

31. Vaira, S.; Johnson, T.; Hirbe, A.C.; Alhawagri, M.; Anwisye, I.; Sammut, B.; O’Neal, J.; Zou, W.; Weilbaecher, K.N.; Faccio, R.; et al. RelB is the NF-kB subunit downstream of NIK responsible for osteoclast differentiation. Proc. Natl. Acad. Sci. USA. 2008, 105, 3897-3902. [CrossRef] [PubMed]

32. Boyce, B.F.; Xiu, Y.; Li, J.; Xing, L.; Yao, Z. NF-кB-Mediated Regulation of Osteoclastogenesis. Endocrinol. Metab. 2015, 30, 35-44. [CrossRef] [PubMed]

33. Wagner, E.; Matsuo, K. Signalling in osteoclasts and the role of Fos/AP1 proteins. Ann. Rheum. Dis. 2003, 62, ii83-ii85. [CrossRef] [PubMed]

34. Anderson, D.M.; Maraskovsky, E.; Billingsley, W.L.; Dougall, W.C.; Tometsko, M.E.; Roux, E.R.; Teepe, M.C.; DuBose, R.F.; Cosman, D.; Galibert, L. A homologue of the TNF receptor and its ligand enhance T-cell growth and dendritic-cell function. Nature 1997, 390, 175-179. [CrossRef] [PubMed]

35. Kanazawa, K.; Kudo, A. Self-assembled RANK induces osteoclastogenesis ligand-independently. J. Bone Miner. Res. 2005, 20, 2053-2060. [CrossRef] [PubMed]

36. He, B.; Weber, G.F. Synergistic activation of the CMV promoter by NF-кB P50 and PKG. Biochem. Biophys. Res. Commun. 2004, 321, 13-20. [CrossRef] [PubMed]

37. Rodova, M.; Jayini, R.; Singasani, R.; Chipps, E.; Islam, M.R. CMV promoter is repressed by p53 and activated by JNK pathway. Plasmid 2013, 69, 223-230. [CrossRef] [PubMed]

38. Weiss, B.; Prozialeck, W.C.; Wallace, T.L. Interaction of drugs with calmodulin. Biochemical, pharmacological and clinical implications. Biochem. Pharmacol. 1982, 31, 2217-2226. [CrossRef]

39. Nagel, D.; Bognar, M.; Eitelhuber, A.C.; Kutzner, K.; Vincendeau, M.; Krappmann, D.; Nagel, D.; Bognar, M.; Eitelhuber, A.C.; Kutzner, K.; et al. Combinatorial BTK and MALT1 inhibition augments killing of CD79 mutant diffuse large B cell lymphoma. Oncotarget 2015, 6, 42232-42242. [CrossRef] [PubMed]

40. Howes, A.; O’Sullivan, P.A.; Breyer, F.; Ghose, A.; Cao, L.; Krappmann, D.; Bowcock, A.M.; Ley, S.C. Psoriasis mutations disrupt CARD14 autoinhibition promoting BCL10-MALT1-dependent NF- $\mathrm{kB}$ activation. Biochem. J. 2016, BCJ20160270. [CrossRef]

41. Afonina, I.S.; Van Nuffel, E.; Baudelet, G.; Driege, Y.; Kreike, M.; Staal, J.; Beyaert, R. The paracaspase MALT1 mediates CARD14-induced signaling in keratinocytes. EMBO Rep. 2016, 17, 914-927. [CrossRef] [PubMed]

42. Douanne, T.; Gavard, J.; Bidère, N. The paracaspase MALT1 cleaves the LUBAC subunit HOIL1 during antigen receptor signaling. J. Cell. Sci. 2016. [CrossRef] [PubMed]

43. Elton, L.; Carpentier, I.; Staal, J.; Driege, Y.; Haegman, M.; Beyaert, R. MALT1 cleaves the E3 ubiquitin ligase HOIL-1 in activated T cells, generating a dominant negative inhibitor of LUBAC-induced NF- $\mathrm{BB}$ signaling. FEBS J. 2016, 283, 403-412. [CrossRef] [PubMed]

44. Bonsignore, L.; Passelli, K.; Pelzer, C.; Perroud, M.; Konrad, A.; Thurau, M.; Stürzl, M.; Dai, L.; Trillo-Tinoco, J.; Del Valle, L.; et al. A role for MALT1 activity in Kaposi's sarcoma-associated herpes virus latency and growth of primary effusion lymphoma. Leukemia 2017, 31, 614-624. [CrossRef] [PubMed] 
45. Lee, C.H.; Bae, S.J.; Kim, M. Mucosa-associated lymphoid tissue lymphoma translocation 1 as a novel therapeutic target for rheumatoid arthritis. Sci. Rep. 2017, 7. [CrossRef] [PubMed]

46. Bardet, M.; Unterreiner, A.; Malinverni, C.; Lafossas, F.; Vedrine, C.; Boesch, D.; Kolb, Y.; Kaiser, D.; Glück, A.; Schneider, M.A.; et al. The T-cell fingerprint of MALT1 paracaspase revealed by selective inhibition. Immunol. Cell. Biol. 2018, 96, 81-99. [CrossRef] [PubMed]

47. Lork, M.; Kreike, M.; Staal, J.; Beyaert, R. Importance of Validating Antibodies and Small Compound Inhibitors Using Genetic Knockout Studies-T Cell Receptor-Induced CYLD Phosphorylation by IKK $\varepsilon / T B K 1$ as a Case Study. Front. Cell. Dev. Biol. 2018, 6, 40. [CrossRef] [PubMed]

48. Bowes, H.A. The ataractic drugs: The present position of chlorpromazine, frenquel, pacatal, and reserpine in the psychiatric hospital. Am. J. Psychiatry 1956, 113, 530-539. [CrossRef] [PubMed]

49. Whittier, J.R.; Klein, D.F.; Levine, G.; Weiss, D. Mepazine (pacatal): Clinical trial with placebo control and psychological study. Psychopharmacologia 1960, 1, 280-287. [CrossRef] [PubMed]

50. Food and Drug Administration. Federal Register, 1998, 63:195, 54085. Available online: https://www.gpo. gov/fdsys/pkg/FR-1998-10-08/html/98-26923.htm (accessed on 30 November 2018).

51. Krappmann, D.; Nagel, D.; Schlauderer, F.; Lammens, K.; Hopfner, K.P.; Chrusciel, R.A.; Kling, D.L. (S)-Enantiomer of Mepazine. U.S. Patent 20160137635A1, 19 May 2016.

52. Hamerman, J.A.; Ni, M.; Killebrew, J.R.; Chu, C.L.; Lowell, C.A. The expanding roles of ITAM adapters FcRgamma and DAP12 in myeloid cells. Immunol. Rev. 2009, 232, 42-58. [CrossRef] [PubMed]

53. Barrow, A.D.; Raynal, N.; Andersen, T.L.; Slatter, D.A.; Bihan, D.; Pugh, N.; Cella, M.; Kim, T.; Rho, J.; Negishi-Koga, T.; et al. OSCAR is a collagen receptor that costimulates osteoclastogenesis in DAP12-deficient humans and mice. J. Clin. Investig. 2011, 121. [CrossRef] [PubMed]

54. Turnbull, I.R.; Gilfillan, S.; Cella, M.; Aoshi, T.; Miller, M.; Piccio, L.; Hernandez, M.; Colonna, M. Cutting Edge: TREM-2 Attenuates Macrophage Activation. J. Immunol. 2006, 177, 3520-3524. [CrossRef] [PubMed]

55. Shin, H.S.; Sarin, R.; Dixit, N.; Wu, J.; Gershwin, E.; Bowman, E.P.; Adamopoulos, I.E. Crosstalk among IL-23 and DNAX Activating Protein of $12 \mathrm{kDa}$-Dependent Pathways Promotes Osteoclastogenesis. J. Immunol. 2015, 194, 316-324. [CrossRef] [PubMed]

56. Harre, U.; Lang, S.C.; Pfeifle, R.; Rombouts, Y.; Frühbeißer, S.; Amara, K.; Bang, H.; Lux, A.; Koeleman, C.A.; Baum, W.; et al. Glycosylation of immunoglobulin $\mathrm{G}$ determines osteoclast differentiation and bone loss. Nat. Commun. 2015, 6, 6651. [CrossRef] [PubMed]

57. Zaiss, M.M.; Sarter, K.; Hess, A.; Engelke, K.; Böhm, C.; Nimmerjahn, F.; Voll, R.; Schett, G.; David, J.P. Increased bone density and resistance to ovariectomy-induced bone loss in FoxP3-transgenic mice based on impaired osteoclast differentiation. Arthritis Rheum. 2010, 62, 2328-2338. [CrossRef] [PubMed]

58. McKinnon, M.L.; Rozmus, J.; Fung, S.Y.; Hirschfeld, A.F.; Del Bel, K.L.; Thomas, L.; Marr, N.; Martin, S.D.; Marwaha, A.K.; Priatel, J.J.; et al. Combined immunodeficiency associated with homozygous MALT1 mutations. J. Allergy Clin. Immunol. 2014, 133, 1458-1462. [CrossRef] [PubMed]

59. Rozmus, J.; McDonald, R.; Fung, S.Y.; Del Bel, K.L.; Roden, J.; Senger, C.; Schultz, K.R.; McKinnon, M.L.; Davis, J.; Turvey, S.E. Successful clinical treatment and functional immunological normalization of human MALT1 deficiency following hematopoietic stem cell transplantation. Clin. Immunol. Orlando Fla 2016, 168, 1-5. [CrossRef] [PubMed]

60. Ishiguro, K.; Ando, T.; Goto, H.; Xavier, R. Bcl10 is phosphorylated on Ser138 by Ca ${ }^{2+} /$ calmodulin-dependent protein kinase II. Mol. Immunol. 2007, 44, 2095-2100. [CrossRef] [PubMed]

61. Oruganti, S.R.; Edin, S.; Grundström, C.; Grundström, T. CaMKII targets Bcl10 in T-cell receptor induced activation of NF-кB. Mol. Immunol. 2011, 48, 1448-1460. [CrossRef] [PubMed]

62. Ishiguro, K.; Green, T.; Rapley, J.; Wachtel, H.; Giallourakis, C.; Landry, A.; Cao, Z.; Lu, N.; Takafumi, A.; Goto, H.; et al. $\mathrm{Ca}^{2+} /$ calmodulin-dependent protein kinase II is a modulator of CARMA1-mediated NF- $\mathrm{kB}$ activation. Mol. Cell. Biol. 2006, 26, 5497-5508. [CrossRef] [PubMed]

63. Frischbutter, S.; Gabriel, C.; Bendfeldt, H.; Radbruch, A.; Baumgrass, R. Dephosphorylation of Bcl-10 by calcineurin is essential for canonical NF-kB activation in Th cells. Eur. J. Immunol. 2011, 41, 2349-2357. [CrossRef] [PubMed]

64. Ferraccioli, G.F.; Tomietto, P.; De Santis, M. Rationale for T cell inhibition by cyclosporin A in major autoimmune diseases. Ann. N. Y. Acad. Sci. 2005, 1051, 658-665. [CrossRef] [PubMed]

65. Ruland, J.; Duncan, G.S.; Wakeham, A.; Mak, T.W. Differential requirement for Malt1 in T and B cell antigen receptor signaling. Immunity 2003, 19, 749-758. [CrossRef] 
66. Takahashi, N.; Yamana, H.; Yoshiki, S.; Roodman, G.D.; Mundy, G.R.; Jones, S.J.; Boyde, A.; Suda, T. Osteoclast-like cell formation and its regulation by osteotropic hormones in mouse bone marrow cultures. Endocrinology 1988, 122, 1373-1382. [CrossRef] [PubMed]

67. Staal, J.; Driege, Y.; Haegman, M.; Borghi, A.; Hulpiau, P.; Lievens, L.; Gul, I.S.; Sundararaman, S.; Gonçalves, A.; Dhondt, I.; et al. Ancient Origin of the CARD-Coiled Coil/Bcl10/MALT1-Like Paracaspase Signaling Complex Indicates Unknown Critical Functions. Front. Immunol. 2018, 9. [CrossRef] [PubMed]

68. Brüstle, M. Chemtool-Moleküle zeichnen mit dem Pinguin. Nachrichten Aus Chem. 2010, 49, $1310-1313$. [CrossRef]

Sample Availability: Mepazine and other products used in this study are commercially available from multiple sources, and the plasmids used are available via the BCCM/GeneCorner plasmid collection. MALT1 KO HEK293T cells are available from the authors upon request.

(C) 2018 by the authors. Licensee MDPI, Basel, Switzerland. This article is an open access article distributed under the terms and conditions of the Creative Commons Attribution (CC BY) license (http://creativecommons.org/licenses/by/4.0/). 